DISTRIBUTION SHEET

\begin{tabular}{|c|c|c|c|c|c|}
\hline To & \multicolumn{3}{|l|}{ From } & \multicolumn{2}{|c|}{ Page 1 of 1} \\
\hline Distribution & \multicolumn{3}{|c|}{ M.E. Borgeson } & \multicolumn{2}{|c|}{ Date $11 / 7 / 94$} \\
\hline \multicolumn{4}{|l|}{ Project Title/Work Order } & EDT No. & 608804 \\
\hline \multicolumn{4}{|c|}{$\begin{array}{l}\text { Project 95L-EWT-100, Hazardous Materials Management and } \\
\text { Emergency Response Training Center, WHC-SD-T100-QAPP-001 }\end{array}$} & \multicolumn{2}{|c|}{ ECN No. N/A } \\
\hline NAME & MSIN & $\begin{array}{c}\text { Text } \\
\text { With All } \\
\text { Attach. }\end{array}$ & $\begin{array}{l}\text { Text } \\
\text { Only }\end{array}$ & $\begin{array}{l}\text { Attach./ } \\
\text { Appendix } \\
\text { Only }\end{array}$ & $\begin{array}{c}\text { EDT/ECN } \\
\text { Only }\end{array}$ \\
\hline $\begin{array}{l}\text { L.S. Ayre } \\
\text { B.G. Baker } \\
\text { F.D. Beard (2) } \\
\text { M.E. Borgeson (10) } \\
\text { G.B. Becker } \\
\text { D.J. Carrell } \\
\text { W.S. Chin } \\
\text { D.J. Donnelly } \\
\text { P.L. Fitzgibbons } \\
\text { W.R. Hayes } \\
\text { J.R. Kelly } \\
\text { K.I. Lane } \\
\text { K.A. McGinnis } \\
\text { P.J. McKenna } \\
\text { C.E. Norton } \\
\text { J.E. Ollero } \\
\text { R.H. Palmer } \\
\text { L.D. Salsberry } \\
\text { S.W. Seiler } \\
\text { D.L. Street (5) } \\
\text { P.J. Vandervert } \\
\text { Project Files } \\
\text { Central Files (2 + Original) } \\
\text { O.S.T.I. (2) }\end{array}$ & $\begin{array}{l}\text { HO-57 } \\
\text { L6-57 } \\
\text { A5-18 } \\
\text { HO-57 } \\
\text { R3-28 } \\
\text { H6-22 } \\
\text { A5-18 } \\
\text { G6-57 } \\
\text { H5-26 } \\
\text { S3-97 } \\
\text { R3-28 } \\
\text { L4-93 } \\
\text { HO-57 } \\
\text { R3-54 } \\
\text { E6-03 } \\
\text { A } 1-55 \\
\text { R2-58 } \\
\text { E6-03 } \\
\text { G3-10 } \\
\text { A5-2O } \\
\text { HO-57 } \\
\text { R1-28 } \\
\text { L8-04 } \\
\text { L8-07 }\end{array}$ & $\begin{array}{l}X \\
X \\
X \\
X \\
X \\
X \\
X \\
X \\
X \\
X \\
X \\
X \\
X \\
X \\
X \\
X \\
X \\
X \\
X \\
X \\
X \\
X \\
X \\
X\end{array}$ & & & \\
\hline
\end{tabular}




\section{DISCLAIMER}

Portions of this document may be illegible in electronic image products. Images are produced from the best available original document. 


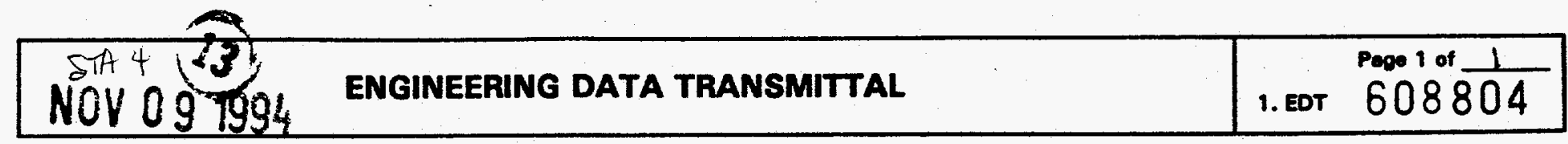

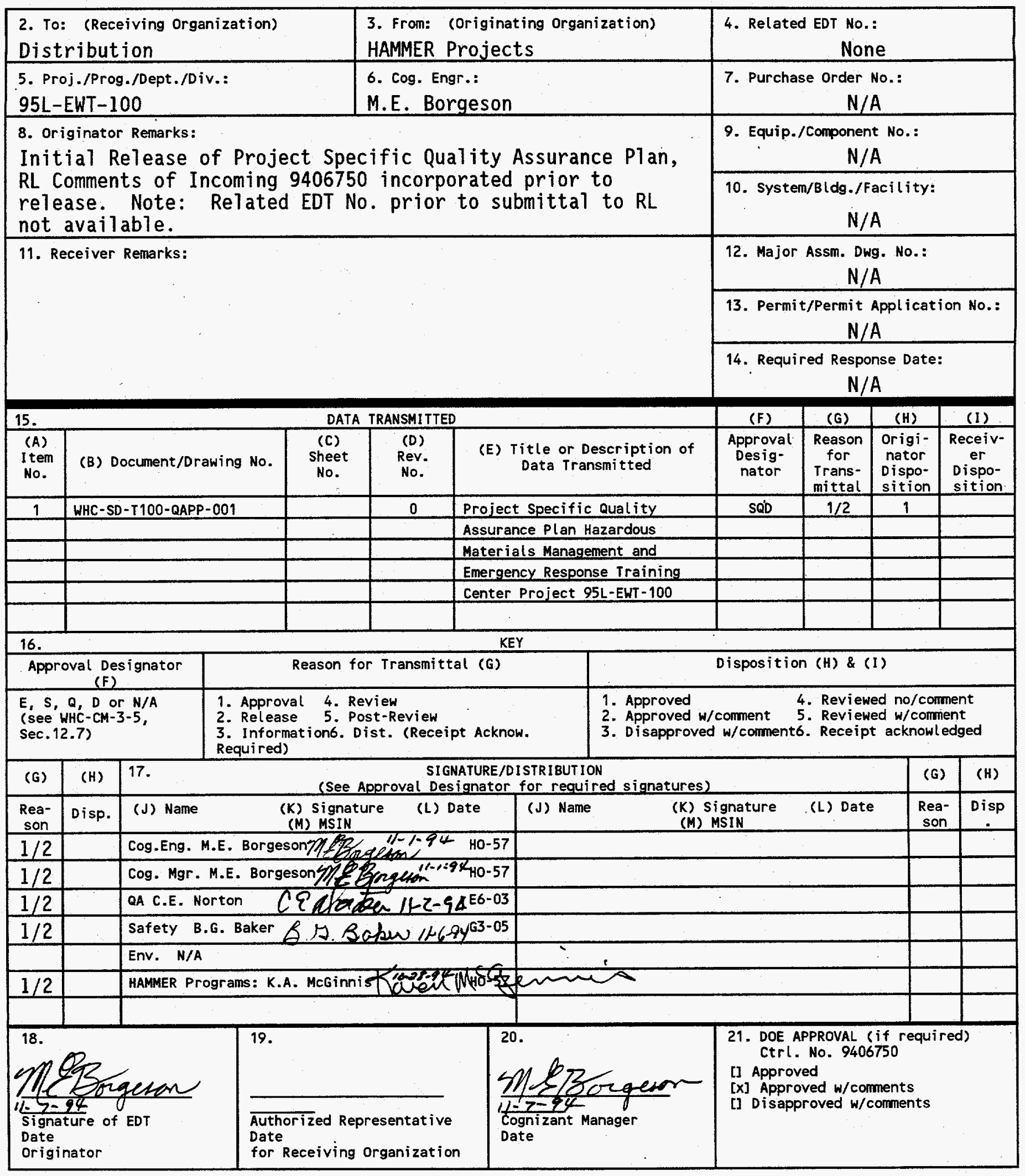

BD-7400-172-2 (04/94) GEF097 


\section{RELEASE AUTHORIZATION}

Document Number: WHC-SD-T100-QAPP-001, REV.0

Document Title:

PROJECT T100 - HAZARDOUS MATERIALS MANAGEMENT AND EMERGENCY RESPONSE TRAINING CENTER (HAMMER)

Release Date: $\quad$ November 9, 1994

\section{This document was reviewed following the procedures described in WHC-CM-3-4 and is:}

\section{APPROVED FOR PUBLIC RELEASE}

\section{WHC Information Release Administration Specialist:}

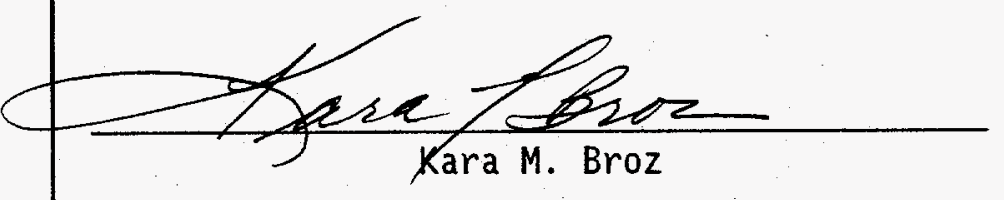

November 9, 1994

TRADEMARK DISCLAIMER. Reference herein to any specific commercial product, process, or service by trade name, trademark, manufacturer, or otherwise, does not necessarily constitute or imply its endorsement, recommendation, or favoring by the United States Government or any agency thereof or its contractors or subcontractors.

This report has been reproduced from the best available copy. Available in paper copy and microfiche. Printed in the United States of America. Available to the U.S. Department of Energy and its contractors from:

U.S. Department of Energy office of Scientific and Technical Information (OSTI) P.0. Box 62 Oak Ridge, IN 37831

Telephone: (615) 576-8401

Available to the public from:

U,S. Department of Cormerce

National Technical Information Service (NTIS)

5285 Port Royal Road

Springfield, VA 22161

Telephone: (703) 487-4650 


\section{SUPPORTING DOCUMENT}

2. Title

PROJECT T100 - HAZARDOUS MATERIALS MANAGEMENT AND EMERGENCY RESPONSE TRAINING CENTER (HAMMER)

5. Key Words

QAPP WHC-SD-T100-QAPP-001, HAMMER, EMERGENCY RESPONSE TRAIING CENTER

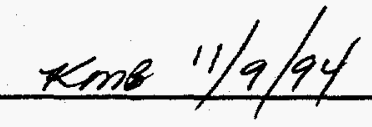

APPROVED FOR PUBLIC RELEASE

3. Number

WHC-SD-T 100-QAPP001

6. Author

Name: C.E. NNORTON

centaka

signature

Organization/Charge Code
1. Total Pages 12

7. Abstract

This document provides Quality Assurance Requirements for Project T100

8. RELEASE STAMP

OFFICIAL RELEASE

BYWHS sis 4 
PROJECT SPECIFIC QUALITY ASSURANCE PLAN

$\mathrm{T} 100$

\title{
HAZARDOUS MATERIALS MANAGEMENT AND EMERGENCY RESPONSE TRAINING CENTER
}

\author{
Issued By: \\ Westinghouse Hanford Company
}

AUGUST 4, 1994

For

U.S. Department of Energy Richland Operations Office Richland, Washington

WhiC Approvals:

Department of Energy Approval:

\section{$\frac{\text { C.E. NORTON CENOSten }}{\text { Cognizant Quality Engineer }}$ \\ L.D. SALSBERRY KC Comier f.o.s. Level 4 - Quality Assurance Manager

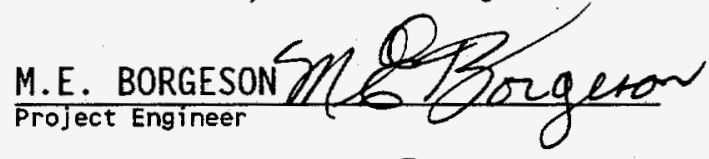

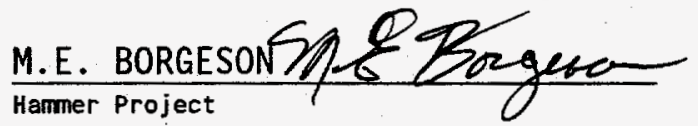 \\ $\frac{\text { B.G. BAKER } \beta \text {. } \beta \text {. Batety operations support }}{\text { Safen }}$

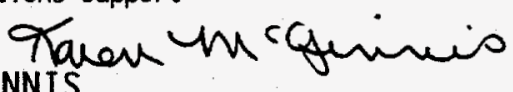

K.A. McGINNIS

Economic Transition - HAMMER

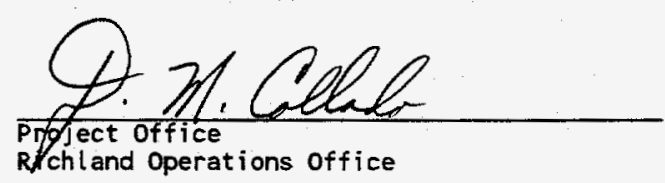

$\frac{8-5-94}{\text { Date. }}$

$8-8-94$

$\frac{8-15-94}{\text { Date }}$

$\frac{8-15-94}{\text { Date }}$

$\frac{9-7-94}{\text { Date }}$

$8-16-9<1$

Date

$\frac{10-24-94}{\text { Date }}$ 
WHC-SD-T100-QAPP-001 Rev. 0

\section{TABLE OF CONTENTS}

Page

Project Scope .................. 3

Responsibilities . . . . . . . . . . . . 3

\section{DISCLAIMER}

This report was prepared as an account of work sponsored by an agency of the United States Government. Neither the United States Government nor any agency thereof, nor any of their employees, makes any warranty, express or implied, or assumes any legal liability or responsibility for the accuracy, completeness, or usefulness of any information, apparatus, product, or process disclosed, or represents that its use would not infringe privately owned rights. Reference herein to any specific commercial product, process, or service by trade name, trademark, manufacturer, or otherwise does not necessarily constitute or imply its endorsement, recommendation, or favoring by the United States Government or any agency thereof. The views and opinions of authors expressed herein do not necessarily state or reflect those of the United States Government or any agency thereof. 


\subsection{SCOPE}

The scope of this Quality Assurance Program Plan (QAPP) is to provide a system of Quality Assurance reviews and verifications on the design and construction of the Hazardous Materials Management and Emergency Response (HAMMER) Training Center, project 95L-EWT100 .

The reviews and verifications will be on activities associated with design, procurement, and construction of the HAMMER project which includes, but is not limited to earthwork, placement of concrete, laying of rail, drilling of wells, water and sewer 1 ine fabrication and installation, communications systems, fire protection/detection systems, line tie-ins, building and mock-up (prop) construction, electrical, instrumentation, pump and valves, and special coatings. The full project scope is defined in the project Functional Design Criteria (FDC), SD-T100-FDC-001, and al1 activities must be in compliance with this FDC.

\subsection{RESPONSIBILITIES}

The Department of Energy (DOE) has the responsibility for the project. DOE has assigned individual contractors the functional responsibility for installing and implementing Quality Assurance in accordance with their contractual requirements, as stated in DOE Order 4700.1, Section III, Part D, and compliant to DOE Order $5700.6 \mathrm{c}$.

The Architect/Engineer (A/E), U.S. Army Corps of Engineers (USACE) is responsible for definitive design, construction and procurement, and preparation of specifications for all activities. The $A / E$ is responsible to ensure that design and construction of the project is in accordance with the latest edition and amendment of the codes and standards noted in the FDC (WHC-SD-T100-FDC-001). If the $A / E$ deems it necessary to expand or delete any of the quality requirements of this plan, all changes shall be approved by the Operating Contractor (OC), Westinghouse Hanford Company (WHC).

The $O C$, WHC, is responsible for the technical direction of the project as noted in RLIP 4700.1 a, chapter III, para 4.a. The OC Quality Assurance Department will provide overall quality performance assessment of the project using document reviews, surveillances, and oversight of quality activities for the project within the guidelines defined in DOE Order $5700.6 \mathrm{C}$. The $O C$ may impose hold or witness points for the purpose of project quality assessment at any point during the project. 
The USACE as Construction Manager (CM), is responsible for performing quality activities as required in specifications and in drawings and inspection plans, and conducting the acceptance tests to demonstrate acceptability.

The Fixed Price Contractor (FPC) who is awarded contract portions by the CM is responsible for performing first line inspections of work under his contract, and ensuring qual ity performance of his portion of the work. The FPC is responsible to provide visible evidence of required inspections and tests such that the results of said inspections and tests are documented and readily apparent.

The USACE shall provide Acceptance Inspection (AI) for overview and acceptance for the government. The USACE is responsible for the performance of AI on all construction activities. The AI organization shall assure all verification/acceptance documentation is accurate and submitted to the $O C$ in a timely manner at project completion, or for review as requested.

Project Organization Chart (Attachment 3) pictorially depicts the project hierarchy.

\subsection{QUALITY ASSURANCE PROGRAM REQUIREMENTS}

The Project Critical Characteristics (Attachment 1) denotes the Safety Class of systems, components and/or structures relevant to the project scope. Quality Assurance programs shall, as a minimum, be commensurate with the defined safety class of the project.

The contractor(s) verifying, inspecting and/or accepting specification and drawing requirements on Safety $\mathrm{Class} 3$ systems components or structures (including occupational safety items) shall maintain a quality program or set of conventional industrial standards which address the following activities as a minimum:

a) A method for control of design from definitive design, change control, configuration control, interface control, through and including as-built controls.

b) A method for control of documentation changes commensurate with the impact of such changes.

c) A method for control of nonconforming condition evaluations and dispositions, including the corrective actions necessary to assure implementation.

d) A method of identifying, defining, controlling and retaining quality related project records. 
e) A method of identification and control of inspection activities (e.g. Inspection Planning and Hold point identification) from the definitive design phase through final project completion.

f) A method of identification and control of testing procedure(s) and/or specification(s). Special test equipment requirements shall be identified in the design documents where appropriate.

g) As specified in the applicable codes/standards;

1) Qualified personnel performing engineering, welding, inspections, and/or testing (e.g. Registered

Professional Engineers performing design verifications, if required).

2) Organizational structure assuring independence of personnel performing the work and those performing the acceptance activities.

h) Approved methods for design verifications of applicable safety classification - Class 3 items shall be established and performed where specified by the $O C$.

i) Where the use of computer codes is required in the design process; the methods for verification, validation, and control of the codes shall be established and maintained.

Contractor(s) performing safety classification - Class 3 verifications, inspections, or acceptance to Project drawings and specifications shall be controlled by conventional industrial codes and standards, as specified in the approved definitive design documents.

Construction Contractor(s) sha1l be responsible for recommending disposition of all nonconformances, including those detected by the $O C, A / E$ or his designee, identified against contractor materials or workmanship.

Nonconforming items identified onsite are to be documented by the construction contractor or his designee. Nonconforming items identified by the contractor offsite requiring a "use as is" or "repair" disposition shall be documented by the contractor on a nonconformance report and submitted to the construction contractor and $\mathrm{OC}$ for approval. 
Nonconforming materials, equipment or workmanship shall be immediately segregated from acceptable items if possible and clearly marked by tagging, or equivalent method, to preclude further processing until the nonconformance has been reviewed, dispositioned as directed by the construction manager, and resolved. Nonconforming materials, equipment or workmanship shall be corrected, repaired or replaced in accordance with the approved corrective action procedure. Proposed methods for corrections or repairs shall be submitted to the $C M$ and $O C$ for review and approval before use.

For nonconformances that, if allowed to continue or exist without correction or repair, would affect the quality of impending work, the Construction Contractor will issue a Stop Work Order. The contractor shall stop all work identified in the stop work order to prevent the performance of work before correction or repair of the nonconformance. Work (as covered in the stop work order) performed by the contractor after issue of a stop work order, but before receipt of a release order, shall be replaced. Upon satisfactory correction or repair of the nonconformance, the Construction Contractor will issue a release order to allow construction to continue.

'Design change' documentation shall not be used to correct a nonconforming condition by change of design unless as a disposition to a nonconformance document (deficiency or nonconformance report with "repair" or "use as is" disposition) issued to address the nonconforming condition. Design change documents issued in response to nonconformance documentation shall bear the number of the nonconformance documentation directing the issuance of the design change document.

\subsection{QUALITY INDEX OF IMPLEMENTING PROCEDURES}

The Architect-Engineer shall identify, in the definitive design documents, those procedures or work standards required to be prepared, followed, and/or submitted by Construction Contractor and Acceptance Inspection group. As a minimum, procedures and work standards sha11 address QA requirements as identified on Attachment 2 of this QA PIan.

The Construction Contractor shall supply the required procedures or work standards or index to be utilized during the project based upon the definitive design document requirements.

Submitted procedures and/or work standards shall comply with the requirements specified in the definitive design documents.

The Construction Contractor's submittal of procedures or work standards required by the definitive design documents will provide the basis for selecting subject material for review, 
surveillance, and/or audits of the project activities by the $O C$, $A / E$, and/or $A I$ to assure compliance to project requirements.

The Operating Contractor shall use appropriate procedures, manuals, and standards during the course of the project from the attached index of implementing procedures, "Quality Assurance Program Index", Attachment 2. The information supplied in the index will be revised only upon a complete major revision of the Manuals and/or standards. The index is intended to show the implementation of the quality assurance program by the Operating Contractor.

The Fixed Price Contractor shall use appropriate procedures, manuals and standards during performance of his portion of the work so as to ensure adequate quality performance in accordance with the contract documents. He shall prepare a matrix of procedures similar to attachment 2 to provide a "Quality Assurance Program Index". 
ATTACHMENT 1

\begin{tabular}{|c|c|c|c|c|c|c|}
\hline \multicolumn{7}{|c|}{ PROJECT CRITICAL CHARACTERISTICS } \\
\hline \multirow{2}{*}{ Item } & \multirow{2}{*}{$\begin{array}{l}\text { Description of Systems, components, } \\
\text { and structures }\end{array}$} & \multirow{2}{*}{ Safety } & \multicolumn{3}{|c|}{$\begin{array}{c}\text { Type of } \\
\text { Inspection }\end{array}$} & \multirow{2}{*}{$\begin{array}{l}F=\text { Functional comments } \\
G=\text { General } \\
D=\text { Detailed }\end{array}$} \\
\hline & & & $F$ & $G$ & D & \\
\hline & SITEWORK & & & & & \\
\hline \multirow[t]{2}{*}{1.} & Fencing & 4 & & $x$ & & \\
\hline & CONCRETE & & & & & \\
\hline 1. & Cast-in-Place Concrete & 4 & & $x$ & & \\
\hline \multirow[t]{2}{*}{2.} & Foundations & 4 & & $x$ & & \\
\hline & METALS & & & & & \\
\hline 1. & Misc Metals & 4 & & $x$ & & \\
\hline \multirow[t]{2}{*}{2.} & Metal Fabrications & 4 & & $\underline{x}$ & & \\
\hline & THERMAL AND MOISTURE PROT & & & & & \\
\hline 1. & Insulation & 4 & & $x$ & & \\
\hline \multirow[t]{2}{*}{2.} & Vapor membrane & 4 & & $x$ & & \\
\hline & INSTRUMENTATION & & & & & \\
\hline 1. & $\begin{array}{l}\text { Annunciation and } \\
\text { indication. }\end{array}$ & 4 & $x$ & $x$ & & \\
\hline \multirow[t]{2}{*}{2.} & $\begin{array}{l}\text { Prop burn and control } \\
\text { circuitry, annunciation and } \\
\text { indication }\end{array}$ & 3 & $x$ & $x$ & & \\
\hline & FINISHES & & & & & \\
\hline \multirow[t]{2}{*}{1.} & Special Protective Coating & 4 & & $x$ & & \\
\hline & PIPING & & & & & \\
\hline 1. & Fire Protection Piping & 3 & & $x$ & $\underline{x}$ & \\
\hline 2. & Piping Services & 4 & & $x$ & & \\
\hline \multirow[t]{2}{*}{3.} & LPG/Natural gas Piping & 3 & & $x$ & $\underline{x}$ & \\
\hline & ELECTRICAL & & & & & \\
\hline 1. & Service and Distribution & 3 & & $x$ & & \\
\hline 2. & Emer Lighting & 3 & $x$ & $x$ & & \\
\hline
\end{tabular}


ATTACHMENT 1

\section{PROJECT CRITICAL CHARACTERISTICS}

\begin{tabular}{|c|c|c|c|c|c|c|}
\hline \multirow{2}{*}{ Item } & \multirow{2}{*}{$\begin{array}{c}\text { Description of Systems, Components, } \\
\text { and Structures }\end{array}$} & \multirow{2}{*}{ Safety } & \multicolumn{3}{|c|}{$\begin{array}{c}\text { Type of } \\
\text { Inspection }\end{array}$} & \multirow{2}{*}{$\begin{array}{l}F=\text { Functional Corments } \\
G=G \text { General }\end{array}$} \\
\hline & & & $\mathbf{F}$ & $G$ & D & \\
\hline 3. & Heat Tracing Systems & 3 & & $x$ & & \\
\hline 4. & Vault Wiring & 3 & & $x$ & & \\
\hline 5. & Pump and Valve Control & 3 & $x$ & $x$ & & \\
\hline 6. & $\begin{array}{l}\text { Firefighting control } \\
\text { computer }\end{array}$ & 3 & $x$ & $x$ & & \\
\hline 7. & $\begin{array}{l}\text { Safety/Shutdown systems for } \\
\text { burn props }\end{array}$ & 3 & $x$ & & $x$ & \\
\hline 6. & Cathodic Protection & 4 & & $\mathrm{x}$ & & \\
\hline 7. & $\begin{array}{l}\text { In-Building distribution } \\
\text { for Training Tower and Burn } \\
\text { Building }\end{array}$ & 3 & & $x$ & & \\
\hline \multirow[t]{2}{*}{8.} & Other In-Building Dist & 4 & & $x$ & & \\
\hline & MECHANICAL & & & & & \\
\hline 1. & Valves & 4 & & $x$ & & \\
\hline 2. & Pumps & 4 & & $x$ & & \\
\hline \multirow[t]{2}{*}{3.} & Fire System valves & 3 & & $x$ & & \\
\hline & VENTILATION & & & & & \\
\hline \multirow[t]{2}{*}{1.} & Prop Smoke Exhaust Fans & 3 & $x$ & $x$ & & \\
\hline & TELECOMMUNICATIONS & & & & & \\
\hline 1. & Telephone & 4 & & $\underline{x}$ & & \\
\hline 2. & HLAN & 4 & & $\underline{x}$ & & \\
\hline \multirow[t]{2}{*}{3.} & Video & 4 & & $x$ & & \\
\hline & OTHER & & & & & \\
\hline 1. & $\begin{array}{l}\text { Well drilling and } \\
\text { encasement }\end{array}$ & 4 & & $x$ & & \\
\hline 2. & Paving & 4 & & $x$ & & \\
\hline 3. & $\begin{array}{l}\text { Confined Space Fal1 } \\
\text { Protection Apparatus }\end{array}$ & 3 & & $x$ & & \\
\hline 4. & Gas Bottle fill equipment & 3 & & $x$ & & \\
\hline & & & & & & \\
\hline & & & & & & \\
\hline
\end{tabular}


ATTACHMENT 2

QUALITY ASSURANCE PROGRAM INDEX

\begin{tabular}{|c|c|c|c|c|c|c|}
\hline \multirow{3}{*}{$\begin{array}{c}\text { BASIC } \\
\text { REQUIREMENTS }\end{array}$} & \multirow{3}{*}{$\begin{array}{l}\text { QA } \\
\text { REQUIREMENT } \\
\text { TITLE }\end{array}$} & \multicolumn{5}{|c|}{ IMPLEMENTING PROCEDURES } \\
\hline & & \multicolumn{2}{|c|}{ WHC } & \multicolumn{2}{|l|}{ MANUALS } & \multirow{2}{*}{$\begin{array}{l}\text { OTHER CODES } \\
\text { AND STANDARDS }\end{array}$} \\
\hline & & QA & Admin & Eng & Proj & \\
\hline 1.0 & Program & $\begin{array}{ll}\mathrm{CM} & 4-2 \\
\mathrm{QR} & 2.0 \\
\mathrm{QI} & 2.1 \\
\end{array}$ & $\begin{array}{c}\text { CM-1-1,2 } \\
\text { CM } 1-3 \\
\text { MRP } 5.2 \\
\end{array}$ & $\begin{array}{l}\text { CM } 6.1 \\
\mathrm{EP} 1.12\end{array}$ & CM-6-2 & \\
\hline 2.0 & $\begin{array}{l}\text { Personnel Training } \\
\text { and Qualification }\end{array}$ & $\begin{array}{cc}\text { CM } & 4.2 \\
\text { QI } & 2.3 \\
\text { CM } & 4-8 \\
\text { QAI } & 2.1 \\
\end{array}$ & CM 1-3 & & & \\
\hline 3.0 & Qual ity Improvement & $\begin{array}{c}C M-4-2 \\
Q R \quad 15 \\
\end{array}$ & $\begin{array}{l}C M-1-1 \\
C M-1-3\end{array}$ & CM-6-1 & $C M-6-2$ & \\
\hline 4.0 & $\begin{array}{l}\text { Documents and } \\
\text { Records }\end{array}$ & $\begin{array}{cc}C M-4-2 \\
\text { QR } & 5 \\
\text { QR } & 6 \\
\text { QR } & 17\end{array}$ & $\begin{array}{l}\text { CM-1-3 } \\
\text { CM-3-5 }\end{array}$ & $\begin{array}{l}\text { CM-6-1 } \\
\text { EP } 1.7 \\
\text { EP } 1.12 \\
\text { EP } 1.14 \\
\text { EP } 2.2 \\
\end{array}$ & $C M-6-2$ & \\
\hline 5.0 & Work Processes & $\begin{array}{c}\mathrm{CM} 4-2 \\
\mathrm{QR} 3,5 \\
\mathrm{QR} 8 \\
\mathrm{QR} 12 \\
\mathrm{QR} 13 \\
\end{array}$ & $\mathrm{CM}-1-3$ & $\begin{array}{l}C M-6-1 \\
\mathrm{EP} 1.0\end{array}$ & CM-6-2 & \\
\hline 6.0 & Design & $\begin{array}{c}C M-4-2 \\
Q R 3 \\
Q R 5\end{array}$ & $\begin{array}{l}\text { CM-1-3 } \\
\text { MRP } 5.37 \\
\text { MRP } 5.46 \\
\text { MRP } 6.1\end{array}$ & $\begin{array}{l}\text { CM-6-1 } \\
\text { EP } 1.7 \\
\text { EP } 2.0 \\
\text { EP } 2.2 \\
\text { EP } 4.1 \\
\end{array}$ & CM-6-2 & \\
\hline 7.0 & Procurement & $\begin{array}{c}\text { CM-4-2 } \\
\text { QR } 4 \\
\text { QI } 4.2 \\
\end{array}$ & $\begin{array}{l}C M-1-3 \\
C M-2-1\end{array}$ & CM-6-1 & CM-6-2 & \\
\hline 8.0 & $\begin{array}{l}\text { Inspection and } \\
\text { Acceptance }\end{array}$ & $\begin{array}{c}\text { CM-4-2 } \\
\text { QI } 10.4 \\
\text { QR } 12 \\
\text { QI } 12.2 \\
\text { QR } 14\end{array}$ & $C M-1-3$ & CM-6-1 & $C M-6-2$ & \\
\hline 9.0 & $\begin{array}{l}\text { Management } \\
\text { Assessment }\end{array}$ & $\begin{array}{l}\text { CM-4-2 } \\
\text { QI } 2.7 \\
\text { QR } 16 \\
\end{array}$ & $\begin{array}{l}\text { CM-1-1 } \\
\text { CM-1-3 }\end{array}$ & & & \\
\hline 10.0 & $\begin{array}{l}\text { Independent } \\
\text { Assessment }\end{array}$ & $\begin{array}{c}\text { CM-4-2 } \\
\text { QR } 16 \\
\text { QR } 18 \\
\end{array}$ & $\begin{array}{l}\text { CM-1-3 } \\
\text { CM-7-5 } \\
\text { Part U }\end{array}$ & & $C M-6-2$ & \\
\hline
\end{tabular}




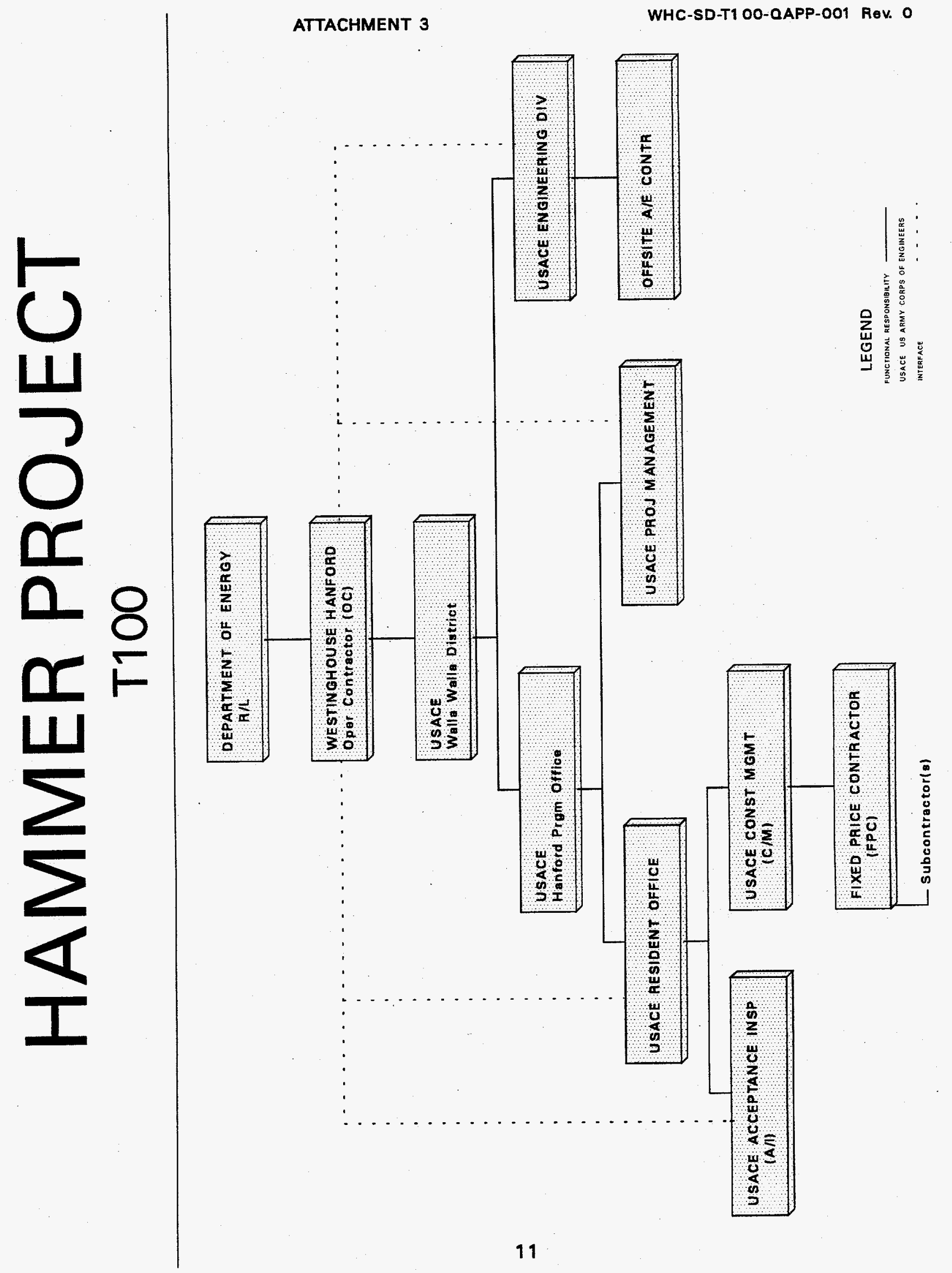

